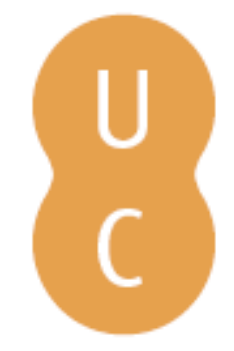

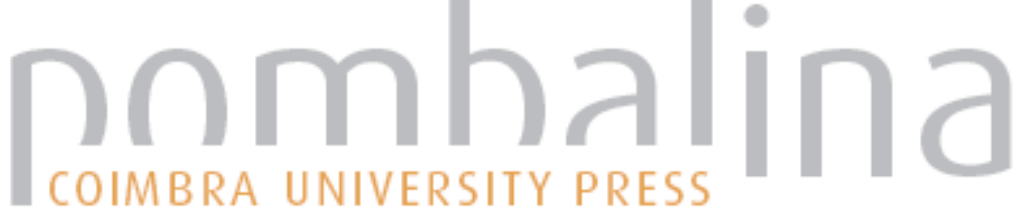

\section{Antisocial behaviours in adolescence: the importance of personal history, present development and future perspective}

\author{
Autor(es): $\quad$ Morgado, Alice Murteira; Dias, Maria da Luz Vale \\ Publicado por: Imprensa da Universidade de Coimbra \\ URL \\ persistente: URI:http://hdl.handle.net/10316.2/38609 \\ DOI: $\quad$ DOI:http://dx.doi.org/10.14195/978-989-26-0775-7_5 \\ Accessed : $\quad$ 26-Apr-2023 15:08:48
}

A navegação consulta e descarregamento dos títulos inseridos nas Bibliotecas Digitais UC Digitalis, UC Pombalina e UC Impactum, pressupõem a aceitação plena e sem reservas dos Termos e Condições de Uso destas Bibliotecas Digitais, disponíveis em https://digitalis.uc.pt/pt-pt/termos.

Conforme exposto nos referidos Termos e Condições de Uso, o descarregamento de títulos de acesso restrito requer uma licença válida de autorização devendo o utilizador aceder ao(s) documento(s) a partir de um endereço de IP da instituição detentora da supramencionada licença.

Ao utilizador é apenas permitido o descarregamento para uso pessoal, pelo que o emprego do(s) título(s) descarregado(s) para outro fim, designadamente comercial, carece de autorização do respetivo autor ou editor da obra.

Na medida em que todas as obras da UC Digitalis se encontram protegidas pelo Código do Direito de Autor e Direitos Conexos e demais legislação aplicável, toda a cópia, parcial ou total, deste documento, nos casos em que é legalmente admitida, deverá conter ou fazer-se acompanhar por este aviso.

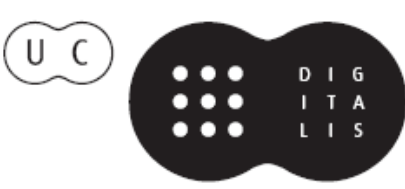




\section{INTERNATIONAL \\ STUDIES IN TIME \\ PERSPECTIVE}

MARIA PAULA PAIXÃO

JOSÉ TOMÁS DA SILVA

(COORD.)

VICTOR ORTUÑO

PEDRO CORDEIRO

(EDITORS)

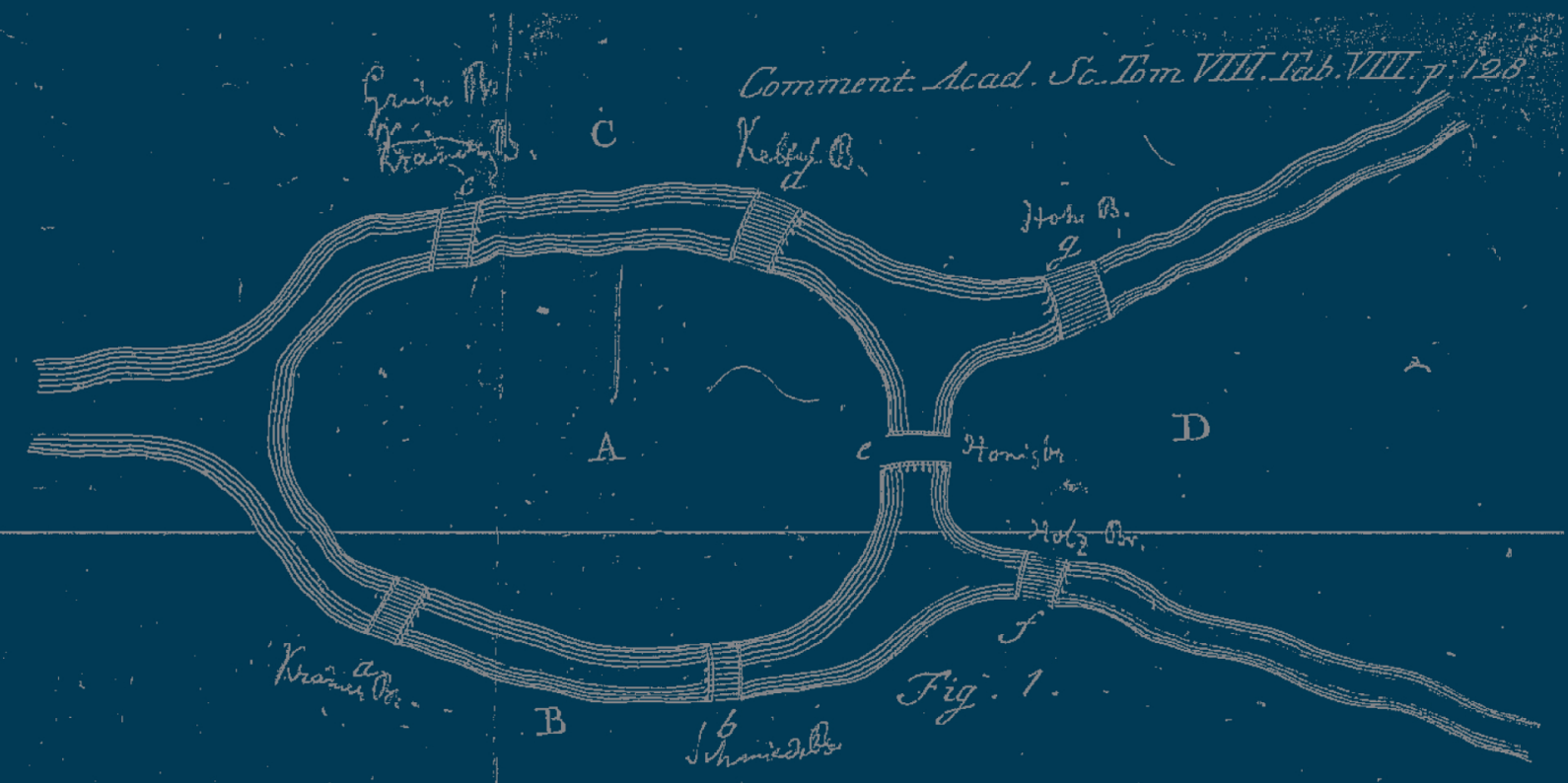

IMPRENSA DA

UNIVERSIDADE

DE COIMBRA

COIMBRA

UNIVERSITY

PRESS 


\title{
Chapter 5 \\ ANTISOCIAL BeHAVIOURS IN ADOLESCENCE: THE IMPORTANCE OF PERSONAL HISTORY, PRESENT DEVELOPMENT AND FUTURE PERSPECTIVE
}

\author{
Alice Murteira Morgado \\ Maria da Luz Vale Dias \\ Faculty of Psychology and Educational Sciences, University of Coimbra, Portugal \\ alicemmorgado@gmail.com \\ valedias@fpce.uc.pt
}

\begin{abstract}
Aвstract: Our work offers a reflection on antisocial behaviours in adolescence that seeks to review and synthesize relevant and prominent perspectives on the subject, focusing on those that come from a developmental point of view. Such a framework implies, thus, a description and explanation of the antisocial phenomenon in its history, development and possible outcomes, more specifically, its etiology, risk and protective factors, developmental trajectories, manifestations, desistance and persistence mechanisms, and degrees of severity. Therefore, the importance of answering specific questions concerning the time at which antisocial manifestations first occur, the origins of such manifestations and the pathways followed before and after is highlighted. In fact, since antisocial acts may take place at different moments in the lifespan, our purpose was to identify the peculiarities of the phenomenon in adolescence, with particular focus on aspects that undergo considerable development at this stage and may play an important role in risk behaviours, namely, future time perspective, self-control, delay of gratification, psychosocial competence and interpersonal relations. The general conclusion of our review shows that several questions remain to be answered, particularly in the Portuguese context. Hence, we present a project of investigation seeking to address some of those issues.
\end{abstract}

Keywords: antisocial, adolescence, developmental, trajectories.

\section{INTRODUCTION}

A general assumption regarding the meaning of antisocial behaviours could be that they describe behaviours that violate social rules intended to promote respect and consideration towards other people's life and property (Burt, Donnellan, Iacono \& McGue, 2011; Kagan, 2004). Such definition makes it clear that the concept of antisocial behaviour is a socially determined construct that may include many different subtypes (from overt to covert), levels of destructiveness, forms (from direct to relational), functions (from instrumental to reactive), onsets (from early to late) and pathways (desistance or persistence). Ultimately, it "must be interpreted as a social event, with meaningful subtypes, topographies, antecedents, and functions" (Dodge, Coie \& Lynam, 2008, p. 437).

Although we can list several examples of possible antisocial acts, the identification and study of antisocial behaviours, especially in adolescence, is defined by a high level of 
uncertainty. Actually, "examples during childhood and adolescence range from more or less normative behaviours, such as lying and underage alcohol use, to rarer but more severe behaviours, such as animal cruelty, theft and assault" (Burt, 2012, p.264). Indeed, not only the manifestations of such behaviours present great variability from individual to individual, but also the very definition of the antisocial act presents a big relativity regarding its classification and level of maladjustment involved. A specific behaviour may be considered antisocial in one culture but may be accepted and viewed as adjusted in another culture. It must be taken into account as well that some antisocial behaviours are almost normative for some groups of individuals, even in societies where they are disapproved. We also need to look at the motivations and levels of pathology that characterize such behaviours, since "some criminal acts represent a highly principled form of civil protest" (Rutter, Giller \& Hagell, 1998, p. 113) and, in some cases, are performed without the intent to cause harm or violate social rules. Particularly, before adulthood, as it will be further explored, the individuals' behaviours may be motivated by a multitude of factors, some of which do not necessarily involve pathology or intent to harm. In other words, "some criminal acts are indeed normal in the triple sense that their motivation is moral rather than antisocial, that the usual risk factors for crime do not apply, and that they do not reflect either social malfunction or personal psychopathology" (Rutter, et al., 1998, 113). Moreover, despite being a serious social and public health matter, antisocial behaviour in adolescence is often difficult to quantify because most acts are not formally reported to health or legal entities.

In this context, and from a developmental perspective, adolescence is viewed as a unique stage of human development with very specific characteristics. It is period when individuals do not only strive to adapt to the environment and seek balance, but also seek to build their own identity. This occurs while multiple and profound physical, cognitive, moral and socioemotional changes take place (Steinberg, 2009; Taborda Simões, 2002). Hence, antisocial behaviours that are manifested at this stage must be analyzed and interpreted within the context of such profound developmental changes and all the underlying complexity and significance.

The complex and heterogeneous nature of antisocial behaviours, especially in adolescence, is, thus, well acknowledged in literature regarding this issue (Rutter, 2004), and there is a wide range of researchers that have been seeking to describe and explain the antisocial phenomenon, as well as its etiology, determinants, related trajectories, manifestations, degrees of severity, and persistence/desistance mechanisms. Developmental theories, in particular, offer an interesting framework on antisocial behaviour that concern, not only a descriptive analysis of antisocial acts and antisocial individuals, but also consider its genesis and possible trajectories. "The assumption of developmental models is that specific risk variables cause children to follow specific developmental trajectories. This implies that changes in these risk variables should influence the course along which these children develop" (vanLier, Vuijk \& Crijnen, 2005, p. 522). Thus, in order to understand the antisocial act from a developmental perspective, we need to understand at what point in the individual's life it occurred, how it was originated, and what pathways (i.e. persistence or desistence, more or less severe antisocial behaviours) were followed by the individual before and after. In the next section we address some of these aspects with a reflection on the specificities and factors that may enlighten our knowledge of adolescent antisocial behaviour, followed by the introduction of a project of investigation aimed at studying the antisocial phenomenon in adolescence from a developmental perspective. 


\section{DeVelopmental ASPECTS: THE IMPORTANCE OF PERSONAL HISTORY, PRESENT DEVELOPMENT, AND FUTURE PERSPECTIVE}

The starting point of our review is the acknowledgment of the heterogeneous character of the antisocial phenomenon, which "constitutes a challenge for theory, research and intervention design" (Moffitt \& Caspi, 2001, p. 355). In fact, the complexity involving antisocial behaviours is evident if we consider the number of different deviant manifestations (that range in nature and severity from running away from home, threats or truancy, to theft, violent attacks or violation, amongst many others) and the diversity of antisocial individuals and possible antisocial trajectories. Laub, Sampson and Sweeten (2006, p. 323) even recognize, at this purpose that "there will always be a considerable heterogeneity in criminal offending no matter how many factors are taken into account".

Regarding adolescence in particular, there is a wide consensus that this developmental stage seems to involve a significant increase in prevalence of antisocial manifestations. Actually, the rapid increase in deviant behaviour during adolescence followed by a rapid decrease after this developmental stage has been named the age crime curve. This is a curve characterized by a rapid increase in deviancy in midadolescence, a peak in late adolescence, a marked decrease in early adulthood (or emerging adulthood) followed by a gradual, monotonic decline (Blonigen, 2010). Explanations for this phenomenon have included biological aspects, such as the rise of testosterone levels and neurological maturation, and sociological aspects, such as the increase in the environment's role and the peers' influence on the individual's conduct, that typically takes place in adolescence (e.g. Blonigen, 2010; Farrington, 2007; Tremblay, 2000). In this regard, Moffitt (1993) argues that both prevalence and incidence of offending are more frequent in adolescence and that criminal offenders are mostly teenagers. According to the author, this occurs because, in childhood, delinquency is more of an individual psychopathology, while in adolescence it becomes almost normative (shifting again to being psychopathological in adulthood).

In fact, distinctions in antisocial behaviours can be set according to several criteria, but age appears to be, if not the main focus, at least an important topic of discussion for many authors. Examples of its importance can be found in several prominent developmental models that consider age-of-onset as the main criteria to define a taxonomy of antisocial behaviours and to characterize the development of deviant trajectories (e.g. Farrington, 2008; Lahey \& Waldman, 2004; Moffitt, 1993, 2003, 2006; Patterson \& Yoerger, 2002a, 2002b; Sampson \& Laub, 2005; Thornberry \& Krohn, 2004; Zara \& Farrington, 2010). In general, a relation between precocity and severity/persistence is pointed out, with the notion that the earlier the onset of deviant behaviours, the more severe and persistent the antisocial path will be: "chronic antisocial behaviour after preadolescence is the continuation of a pattern that begins in early childhood" (Lacourse et al., 2002, p. 909). Indeed, it is believed that, when problems start later in development, individuals may have experienced already some prior positive or prosocial opportunities that can serve as protective factors against a persistent delinquent career (Moffitt, 1993, 2003, 2006; Patterson \& Yoerger, 2002a, 2002b; Thornberry \& Krohn, 2004). Sampson and Laub, however, argue that "crime declines with age even for active offenders and that trajectories of desistance cannot be prospectively identified based on typological accounts rooted in childhood and individual differences" (Sampson \& Laub, 2005, p. 17). Regardless of each particular position, it appears to be consensual that the processes and risk factors 
involved in persistent and chronic antisocial behaviour are different from those involved in adolescencelimited deviancy, which means that the age at which conduct problems are manifested seems to be an important factor to consider when we analyze deviant trajectories.

From a different viewpoint, Tremblay $(2000,2010)$, recognizes the importance of the age at which behaviours manifest for the severity and persistence of antisocial paths, but suggests a differentiation of antisocial behaviours according to types of antisocial manifestations (overt and covert) instead of ageofonset. As Loeber and Schmaling (1985, p. 350) had previously suggested, "it would be fruitful to use distinct treatment approaches for covert and overt patterns of antisocial behaviour, each focusing on separate behaviours and different etiological variables". In this regard, Burt et al. (2011) presented findings from a recent study implying that, contrary to what was anticipated earlier, the age at which antisocial behaviours first manifest is not as important as the behavioural subtypes linked to ageofonset are for the prediction of antisocial trajectories. In fact, research has pointed out to the fact that, not only different antisocial behavioural subtypes may evidence different behavioural trajectories, but also that developmental trajectories of different types of antisocial behaviour may not be driven by the same proximal and causal factors (Burt, 2012; Lacourse et al., 2002). In particular, Burt (2012) concluded that aggressive (overt) behaviours tend to be more consistent over time, while rulebreaking (covert) behaviours tend to be more frequent during adolescence.

Interestingly, it appears that the behavioural subtypes distinction corresponds more or less to the ageofonset distinction: physical aggression is particularly characteristic of childhoodonset antisocial behaviours, whereas rulebreaking is linked to adolescenceonset antisocial behaviours (Burt, 2012). This may be explained by aspects related to socioemotional development, since "one of the major developmental challenges of a child is to learn to inhibit physical aggression and use other patterns of action in his attempts to achieve his goals" (Tremblay, 2010, p. 347). In fact, Patterson and Yoerger suggest that overt forms of antisocial behaviours grow during toddlerhood, whereas in adolescence covert antisocial behaviours tend to be more significant: "the toddler growth spurt is characterized, primarily, by overt forms; whereas the adolescent growth spurt is characterized by massive growth in covert antisocial behaviour accompanied by additional growth in new forms of overt antisocial behaviours" (Patterson \& Yoerger, 2002a, p. 148). Lahey and Waldman's model also typically associates earlyonset of antisocial behaviours to less severe forms of overt behaviours, whereas a later onset appears to be related to covert behaviors and aggressive overt behaviours, in agreement with Moffitt's model, that describes a link between ageofonset and behavioural subtypes (Burt et al., 2011). In sum, it appears that the differences between distinct behavioural subtypes evidence normative aspects of socioemotional development, as reflected by the differences between early and lateonset antisocial behaviour trajectories. In other words, "the AGG [aggressive] and RB [rulebreaking] dimensions appear to capture much of the same information as the age-of-onset types" (Burt, 2012, p. 272).

Regarding the factors involved in the antisocial phenomenon, most authors agree that a wide array of possible variables may contribute to different deviant trajectories. From a thorough analysis, these factors appear to be related to three major groups, that is, individual characteristics, social environment, and family characteristics. Developmental theories stress that the impact of such sets of variables may be different according to the individuals' age or stage of development (Lahey \& Waldman, 2004; Tremblay, 2000, 2010). Indeed, studies from a developmental perspective show that the impact of family, peers and school 
factors differs in different ages during development, with divergences appearing when the relative value of each group of variables is discussed. Moffitt's perspective (1993, 2003, 2006) suggests that aspects such as personality and behaviour are strongly influenced by personenvironment interactions. In other words, "the child acts; the environment reacts; and the child reacts back in mutually interlocking evocative interaction" (Caspi et al., 1987, p. 308 cit in Moffitt, 1993, p. 683). Lahey and Waldman (2004) state that "genetic influences interfere with the environment where behaviour problems are learned, partly due to the effect that the child characteristics (temperament and cognitive skills) exert in that environment" (p. 187-188). Accordingly, Patterson and Yoerger (2002a, 2002b) raise the hypothesis that antisocial trajectories result from a joint effect of biological and environmental variables, and, in Thornberry and Krohn's perspective (2004), the interactions between the individual and the environment originate behavioural patterns, in a reciprocal influence.

The common aspect in developmental psychology is the active role of the individual in its interactions with the environment, that is crucial to define how he/she thinks and judges the social world around him/her. In this sense, "social interactions are involved in the individuals' constructions of moral judgments" (Turiel, 2008, p. 489), while moral judgments may influence social interactions. In this context, adolescence, when social relations assume a growing importance in the individuals' lives, and when psychosocial competences are still far from being fully developed, appear to be a critical stage to identify, prevent and/or compensate for psychosocial vulnerabilities. In fact, many theories on moral judgment and psychosocial maturity highlight the role of these competences in the understanding of antisocial behaviours (Bandura, 2002; Kohlberg, 1981, 1987; Piaget, 1965; Schultz, Barr \& Selman, 2001; Selman, 1975; Selman \& Adalbjarnardottir, 2000), that appear to be determinant, either as protective factor or risk factor, in guiding individual's choices regarding social behaviours (Mota, Matos \& Lemos, 2011; Selman \& Adalbjarnardottir, 2000). These aspects are particularly important to study in childhood and adolescence because psychosocial maturity and tasks that require coordination of affect and cognition are still in development, at least, until young adulthood (Steinberg, 2009). In fact, more immature stages of morality have been identified as risk factors for antisocial behaviours, whereas achieving more mature stages of moral development may protect against deviant conducts (Monahan, Steinberg, Cauffman \& Mulvey, 2009; Stams et al., 2006). Psychosocial maturity is also believed to encourage prosocial and altruistic behaviour, serving as protective factor against several conduct problems. Likewise, perspective-taking ability has been found to lead to more relationship enhancing outcomes, whereas the lack of such competence may contribute to facilitating anger arousal in situations of interpersonal provocation (Mohr, Howells, Gerace, Day \& Wharton, 2007). Moral disengagement has also been strongly linked to antisocial behaviours in childhood and adolescence, as well as to delinquent behaviour (Bandura, Barbaranelli, Caprara \& Pastorelli, 1996; Bandura, Caprara, Barbaranelli, Pastorelli \& Regalia, 2001; Bandura, 2002; Hyde, Shaw \& Moilanen, 2010). In other words, having underdeveloped psychosocial competences appears to encourage antisocial or aggressive behaviour, whereas "to the extent adolescents can develop perspective on the complex connections between their own biological, personal, and cultural relationship histories and their own individual health choices in daily life, they are more likely to keep themselves out of harm's way" (Selman \& Adalbjarnardottir, 2000, 50). 
Hence, morality and psychosocial characteristics - that are clearly so important in the children and adolescents' social experiences - play a very significant role in antisocial behaviours. It is quite consensual that the tendency to show altruism, sympathy, and respect may be determinant in preventing an antisocial trajectory, whereas lack of social sensitivity, empathy and perspective-taking in social interactions may put individuals at higher risk of engaging in antisocial behaviours.

Control also appears to play an important role in antisocial trajectories, either as an individual, social, or family aspect. In fact, theories such as Gottfredson and Hirschi's (1990) and Sampson and Laub's (2005) assign a prominent role to this variable. In the General Theory of Crime (Gottfredson \& Hirschi, 1990), control as an individual feature is highlighted: low selfcontrol appears as the main risk factor for a criminal career. Indeed, personality traits like temper, impulsivity and egocentricity are considered "by-products of self-control and can be rightly used to index levels of self-control" (DeLisi \& Vaughn, 2008, p. 533). In Sampson and Laub's LifeCourse Theory of Crime (2005), control as a social variable is evident in the sense that informal social controls are considered determinant for creating strong bonds between the individual and the society, thus reducing the likelihood of committing a crime. Accordingly, Thornberry and Krohn (2004) stress the role of the individuals' bonds to conventional society in the genesis of delinquency. In addition, some models also acknowledge the importance of control as a family factor: in Patterson and Yoerger's model (2002a, 2002b), changes in problem-solving strategies in the family, discipline, and control (that coincide with the beginning of adolescence) help to explain the late onset of delinquency; Thornberry and Krohn (2004) also mention the lack of parental capacity to establish an effective system of control, monitoring, supervision, reinforcement of prosocial behaviors, and punishment of antisocial behaviours as a risk factor for precocious offending; and Farrington (2004) refers to inadequate supervision as a risk factor for delinquency.

In this context, the study of personality in the scope of antisocial behaviours appears especially pertinent and there is a vast array of literature on this matter that has tested the hypothesis that there are differences in personality between individuals who manifest and do not manifest antisocial tendencies. Actually, a comprehension of an antisocial individual's personality may help to understand his/her social behaviour and vice-versa, thus contributing as part of a model that intends to be extensive and complete. "Taking personality into account implies accepting the existence of cognitive, affective, and behavioural tendencies that may favour delinquency" (Romero, Luengo \& Sobral, 2001, p. 344-345), which means that, more than looking for particular preferences for one or another type of antisocial behaviours, we should focus as well on personality characteristics related to the tendency to break rules and to the refusal/inability to follow social rules

According to Eysenck's theory of personality (Eysenck \& Eysenck, 1985), individuals with antisocial tendencies typically present high scores on the three traits included in the author's model of personality: extroversion, neuroticism, and psychoticism, combined with low scores on the Lie scale (L) from the Eysenck's Personality Questionnaire (EPQ). In this sense, a high score on extroversion would mean that the individual is more difficult to condition and, consequently, has a greater difficulty to inhibit any potential antisocial tendencies. Accordingly, a high level of neuroticism is considered to be related to deviant behaviour in the sense that it is related to anxiety, which is believed to act as a drive or to increase the drive for antisocial behaviour. Finally, high psychoticism is also believed to 
be associated with antisocial behaviour because it describes individuals who are typically egocentric, with reduced sensitivity towards other people's feelings, lack of guilt, and who manifest interpersonal hostility. Unlike the previous traits, psychoticism has gathered more agreement regarding the existence of its strong relation with antisocial behaviour (Carrasco, Barker, Tremblay \& Vitaro, 2006; Center \& Kemp, 2002; Center, Jackson \& Kemp, 2005; Romero et al., 2001). A low score on the Lie scale of EPQ has also been mentioned as a potential characteristic of antisocial individuals, since it may be considered as a measure of socialization and social conformity. In fact, some research has provided evidence that confirms this hypothesis (Center \& Kemp, 2002; Center et al., 2005).

Another interesting theoretical perspective on the subject of personality and antisocial behaviour can be found in Gray's reinforcement sensitivity theory (1991), a model where motivation and emotion play an essential role in personality. The author identified three neurobiological systems of learning that differ according to some of the individual's personality traits: a behavioural inhibition system (BIS), a behavioural approach system (BAS), and a fight/flight/freezing system (FFFS). According to this model, average individuals have balanced systems of inhibition and approach, while antisocial individuals tend to show lower sensitivity to punishment (a weaker BIS) combined with oversensitivity to rewards, that is, a more responsive BAS (Fonseca \& Yule, 1995). The explanation for such imbalance lies on the fact that, for antisocial individuals, deviant behaviours are perceived as rewarding. This does not mean, however, that all individuals perceive equally the same rewards for a given behaviour. In this purpose, Lourenço (2003) mentions the cost-perception/gain-construction hypothesis that, for children, the anticipation of costs in prosocial acts is quite simple, unlike in antisocial acts, where the anticipation of gains appears easier than the anticipation of costs. According to his research, as children develop, their conceptions of gain/cost also develop, and go from a higher anticipation of costs in prosocial acts to higher anticipation of costs in antisocial acts: "it might be the case that the younger, less developed, and more antisocial children display more antisocial behaviour because, among other reasons, they are more likely to think of antisocial acts in terms of gain-perception or affirmation rather than cost-construction or negation" (Lourenço, 2003, p. 29). Also Steinberg (2009) mentions the hypothesis that, despite perceiving risks similarly, adolescents and adults may evaluate rewards (especially when rewards are weighted against the costs) differently, with the former attaching more value to the rewards involved in a risky situation: "what distinguishes adolescents from adults in this regard is not the fact that teens are less knowledgeable about risks, but rather that they attach greater value to the rewards that risk taking provides" (Steinberg, 2004 cit in Steinberg, 2009, p. 469).

Overall, the traits that may influence individuals' attitudes, perceptions and beliefs towards risk taking are included in a common aspect that has been widely pointed out by authors and researchers as characteristic of individuals with antisocial tendencies: impulsivity. Indeed, "boys who were more impulsive have a higher risk of developing antisocial behaviour than those who were not impulsive" (Carrasco et al., 2006, p. 1317). Impulsivity is clearly a consensual prominent characteristic of antisocial individuals (Carrasco et al., 2006; Caspi, 2000; Caspi, Henri, McGee, Moffitt \& Silva, 1995; DeLisi \& Vaughn, 2008; Dodge et al., 2008; Farrington, 2004; Fonseca \& Simōes, 2002; Koolhof, Loeber, Wei, Pardini \& D'Escury, 2007; Moffitt, 1993, 2003, 2006; Romer et al., 2009; Romero et al., 2001; Rutter et al., 1998) and is often mentioned together with references of 
lack of selfcontrol, weak constraint or failure to delay gratification. Interestingly, as a general trait, impulsivity has been found to decline from adolescence to adulthood (Steinberg et al., 2009), which may imply that, in general, as adolescents grow into adulthood, they will tend to become less prone to antisocial behaviours. In fact, it has been suggested that "normative changes in personality may play a significant role in desistance from crime and antisocial behaviour during the transition from late adolescence to early adulthood" (Blonigen, 2010, p. 98). It is also possible that "experience gained during the adolescent period may help adults to recognize the hazards of some forms of risk taking or to provide skills to constrain such activity" (Romer, Duckworth, Sznitman \& Park, 2010, p.327).

Impulsivity has been related to Eysenck's Trait of Psychoticism (Colder et al., 2011), and to a smaller tendency to delay gratification, that is, a smaller tendency to choose a larger, more desired delayed reward instead of a smaller, less desired, but immediate reward. In fact, impulsive individuals tend to choose smaller immediate outcomes more frequently when facing the choice between those and larger delayed outcomes (Baumann \& Odum, 2012). In turn, those who delay gratification appear to be more likely to inhibit risk taking behaviours, being more prone to higher levels of self-control (Romer et al., 2010).

Recent research has also shown that people who are more impulsive tend to overestimate the passing of time (Baumann \& Odum, 2012). This aspect takes us to another very important variable that may underlie individuals' choices regarding risk taking, and may also explain the prevalence of antisocial behaviours in adolescence, that is, time perspective. In fact, adolescents tend to have a weaker future orientation when compared to adults, which may be due to the fact that, "to a young person, a short-term consequence may have far greater salience than one five years in the future. The latter may seem very remote simply because five years represents a substantial portion of her life" (Steinberg, 2009, p. 469). Time perspective may influence an individual's cognitions, attitudes and emotions towards his/her behavioural choices, and adolescence appears as a critical period for development of present and future identity (Husman \& Shell, 2008), determinant for adjusted developmental trajectories. In fact, as previously mentioned, there seems to be a relation between low selfcontrol and immediate pursue of gratification, which may imply an orientation toward the present as opposed to a future time perspective (Monahan et al., 2009). In other words, while individuals who are present oriented tend to adopt preferentially short-term goals and focus on immediate life events and immediate gratification, future oriented individuals tend to have more developed planning abilities, focus on longterm goals and show concern for the future. This means that individuals who maintain a stronger future time perspective tend to be more protected against risk taking and deviant behaviours in the sense that "being future-oriented goes hand in hand with doing appropriate planning, scheduling one's time wisely, and anticipating detours and traps that might appear on the path to success" (Zimbardo \& Boyd, 2010, p.147).

\section{Conclusion}

\section{A project to address adolescent antisocial behaviours}

This review makes it clear that in the antisocial phenomenon there are still many aspects to be enlightened and uncovered due to the complex nature and heterogeneity that 
characterizes it. In the words of Rutter et al. (1998, p. 376): "it is quite simply meaningless to talk or try to explain, or treat antisocial behaviour as if it were of only one «type». It is different in different people, in different situations, and at different times in the life history". Indeed, the role of social environment, the role of family variables and the role of individual characteristics are still far from being understood, especially in what concerns the dynamics and interactions between such sets of factors. Clearly, if possible at all, the identification (and the criteria for categorization) of different antisocial trajectories seems to be far from determined: "there are clearly many developmental trajectories for any given type of antisocial behaviour, and there are possibly different types of developmental trajectories for different types of antisocial behaviour" (Lacourse et al., 2002, p. 921).

Having in mind the state of the art in the subject of antisocial behaviours in adolescence, we seek in future research to better clarify how such behaviours develop and manifest, and to help understanding more fully the underlying variables in play. In order to promote a more profound knowledge and to contribute as well for the explanation of the antisocial phenomenon, antisocial behaviours and interpersonal relations will be studied from a developmental framework. The importance of analyzing some factors becomes thus particularly relevant, specifically, the role of individual, family, and social variables that can be potentially identified as protective or risk factors for the occurrence of behavioural problems. Psychosocial maturity, social skills, selfconcept, personality, intellectual level, gender, family relations, and socioeconomic status will be considered, having always in mind that "a single mechanism by itself rarely functions exclusively as a unitary protective or risk factor for maladjustment” (Ayduk, Rodriguez, Mischel, Shoda \& Wright, 2007, p. 375).

The aim of our project of investigation is, thus, to build a developmental explanatory model for the antisocial phenomenon in adolescence that can provide the possibility of identifying and intervening in risk situations, and that can result in the construction and implementation of prevention programs. Hence, the first issue to be addressed with the collected data is identifying what behaviour problems are manifested in adolescence and what are their characteristics. Secondly, we will identify and describe differences between individuals who manifest antisocial behaviours and those who do not, and between those who engage in different types of deviant behaviour. Gathering such information, we will try to typify different patterns of antisocial behaviour in adolescence, based on their nature, frequency, severity, and onset. The role of each of the above mentioned individual, family and social factors will then be studied, both individually and in relation to the others. We will also try to define the relative weight of each group of variables in influencing antisocial behaviours, and, finally, attempt to find the major risks for antisocial behaviours in adolescence, and what factors protect individuals from such conducts.

\section{REFERENCES}

Ayduk, O., Rodriguez, M. L., Mischel, W., Shoda, Y., \& Wright, J. (2007). Verbal intelligence and selfregulatory competencies: Joint predictors of boys' aggression. Journal of Research in Personality, 41, 374-388. doi: 10.1016/j.jrp.2006.04.008

BANDura, A. (2002). Selective moral disengagement in the exercise of moral agency. Journal of Moral Education, 31(2), 101-119. doi: 10.1080/0305724022014322 
Bandura, A., Barbaranelli, C., Caprara, G. V., \& Pastorelli, C. (1996). Mechanisms of moral disengagement in the exercice of moral agency. Journal of Personality and Social Psychology, 71(2), 364-374. doi: 10.1037/0022-3514.71.2.364

Bandura, A., Caprara, G. V., Barbaranelli, C., Pastorelli, C., \& Regalia, C. (2001). Sociocognitive self-regulatory mechanisms governing transgressive behavior. Journal of Personality and Social Psychology, 80(1), 125-135. doi: 10.1O37//O022-3514.80.1.125

Baumann, A. A., \& Odum, A. L. (2012, in press). Impulsivity, risk taking, and timing. Behavioural Processes. doi: 10.1016/j.beproc.2012.04.005

Blonigen, D. M. (2010). Explaining the relationship between age and crime: Contributions from the developmental literature on personality. Clinical Psychology Review, 30, 89-100. doi: 10.1016/j.cpr.2009.10.001

BurT, S. A. (2012). How do we optimally conceptualize the heterogeneity within antisocial behavior? An argument for aggressive versus nonaggressive behvaioral dimensions. Clinical Psychology Review, 32, 263-279. doi: 10.1016/j.cpr.2012.02.006

Burt, S. A., Donnellan, M. B., Iacono, W. G., \& McGue, M. (2011). Age-of-onset or behavioral sub types? A prospective comparison of two approaches to characterizing the heterogeneity within antisocial behavior. Journal of Abnormal Child Psychology, 39, 633-644. doi: 10.1007/ s10802-011-9491-9

Carrasco, M., Barker, E. D., Tremblay, R. E., \& Vitaro, F. (2006). Eysenck's personality dimensions as predictors of male adolescent trajectories of physiscal aggression, theft and vandalism. Personality and Individual Differences, 41, 1309-1320. doi: 10.1016/j.paid.2006.05.005

Caspr, A. (2000). The child is the father of the man: Personality continuities from childhood to adulthood. Journal of Personality and Social Psychology, 78(1), 158-172. doi: 10.1037//00223514.78.1.158

Caspi, A., Henry, B., McGee, R. O., Moffitt, T. E., \& Silva, P. A. (1995). Temperamental origins of child and adolescent behavior problems: From age three to age fifteen. Child Development, 66, 55-68. doi: 10.1111/1467-8624.ep9503233289

Center, D. B., \& Kemp, D. E. (2002). Anti-social behaviour in children and Eysenck's theory of personality: An evaluation. International Journal of Disability, Development and Education, 49(4), 353-366. doi: 10.1080/1034912022000028330

Center, D. B., Jackson, N., \& Kemp, D. E. (2005). A test of Eysenck's antisocial behavior hypothesis employing 11-15-year-old students dichotomous for PEN and L. Personality and Individual Differences, 38, 395-402. doi: 10.1016/j.paid.2004.04.017

Colder, C. R. et al. (2011). Revised reinforcement sensitivity theory and laboratory assessment of BIS and BAS in children. Journal of Research in Personality, 45, 198-207. doi:10.1016/j. jrp.2011.01.005

DeLisi, M., \& Vaughn, M. G. (2008). The Gottfredson-Hirschi critiques revisited: Reconciling selfcontrol theory, criminal careers, and career criminals. International Journal of Offender Therapy and Comparative Criminology, 52, 520-537. doi: 10.1177/0306624X07308553

Dodge, K. A., Coie, J. D., \& Lynam, D. (2008). Aggression and antisocial behavior in youth. In W. Damon, \& R. M. Lerner, Child and adolescent development: An advanced course (pp.437-472). Hoboken, N.J.: Wiley.

Eysenck, H. J., \& Eysenck, M. W. (1985). Personality and individual differences: A natural science approach. New York: Plenum Press. 
Farrington, D. P. (2004). O estudo do desenvolvimento da delinquência de Cambridge: Principais resultados dos primeiros 40 anos. In A. C. Fonseca (Ed.), Comportamento antisocial e crime: Da infância à idade adulta (pp. 73-132). Coimbra: Almedina.

Farrington, D. P. (2007). Origins of violent behavior over the life span. In D. J. Flannery, Vazsonyi, A. T., \& Waldman, I. D. (eds.), The Cambridge handbook of violent behavior and aggression (pp. 19-48). New York: Cambridge University Press.

FARrington, D. P. (2008). O desenvolvimento do comportamento criminoso e antisocial da infância à idade adulta. In A. Matos, C. Vieira, S. Nogueira, J. Boavida, \& L. Alcoforado (Eds.), A maldade humana: Fatalidade ou educação? (pp.221-245). Coimbra: Almedina.

Fonseca, A. C., \& Simốes, A. (2002). A teoria geral do crime de Gottfredson e Hirschi: O papel do autocontrolo, da família e das oportunidades. In A. C. Fonseca (Ed.), Comportamento anti-social e familia: Uma abordagem cientifica (pp. 245-267). Coimbra: Almedina.

Fonseca, A. C., \& Yule W. (1995) Personality and antisocial behavior in children and adolescents: An enquiry into Eysenck's and Gray's theories. Journal of Abnormal Child Psychology, 23, 767781. doi: $10.1007 / \mathrm{BF} 01447476$

Gottfredson, M. R., \& Hirschi, T. (1990). A general theory of crime. Stanford, CA: Stanford University Press.

Gray, J. A. (1991). Neural systems of motivation, emotion and affect. In J. Madden (Ed.), Neurobiology of learning, emotion and affect (pp. 273-306). New York: Raven Press.

Husman, J., \& Shell, D. F. (2008). Beliefs and perceptions about the future: A measurement of future time perspective. Learning and Individual Differences, 18, 166-175. doi: 10.1016/j. lindif.2007.08.001

Hyde, L. W., Shaw, D. S., \& Moilanen, K. L. (2010). Developmental precursors of moral disengagement and the role of moral disengagement in the development of antisocial behaviour. Journal of Abnormal Child Psychology, 38, 197-209. doi: 10.1007/s10802-009-9358-5

Kagan, J. (2004). Comportamento anti-social: Contributos culturais, vivenciais e temperamentais. In A. C. Fonseca (Ed.), Comportamento anti-social e crime: Da infância à idade adulta (pp. 1-10). Coimbra: Almedina.

Kohlberg, L. (1981). The philosophy of moral development: Moral stages and idea of justice. Cambridge: Harper \& Row.

Kohlberg, L. (1987). The development of moral judgment and moral action. In L. Kohlberg et al., Child psychology and childhood education: A cognitive-developmental view (pp.259-328). New York: Longman.

Koolhof, R., Loeber, R., Wei, E. H., Pardini, D., \& D’Escury, A. C. (2007). Inhibition deficits of serious delinquent boys of low intelligence. Criminal Behaviour and Mental Health, 17, 274292. doi: $10.1002 / \mathrm{cbm} .661$

LACourse, E., et al. (2002). A longitudinal-experimental approach to testing theories of antisocial behavior development. Development and Psychopathology, 14, 909-924. doi: 10.1017. S0954579402004121

Lahey, B. B., \& Waldman, I. D. (2004). Predisposição para problemas de comportamento na infância e na adolescência: Análise de um modelo desenvolvimentista. In A. C. Fonseca (Ed.), Comportamento antisocial e crime: Da infância à idade adulta (pp. 161-214). Coimbra: Almedina.

Laub, J. H., Sampson, R. J., \& Sweeten, G. A. (2006). Assessing Sampson and Laub's lifecourse theory of crime. In F. T. Cullen, J. P. Wright, \& K. R. Blevins, Taking stock: the status of criminological theory. (pp. 313-333). New Brunswick, N.J.: Transaction Publishers. 
Loeber, R., \& Schmaling, K. B. (1985). Empirical evidence for overt and covert patterns of antisocial conduct problems: A metaanalysis. Journal of Abnormal Child Psychology, 13(2), 337352. doi: 10.1007/BF00910652

Lourenço, O. (2003). Children's appraisals of antisocial acts: A Piagetian perspective. The British Journal of Developmental Psychology, 21, 19-31. doi: 10.1348/026151003321164591

Moffitt, T. E. (1993). Adolescence-limited and life-course persistent anti-social behavior: A developmental taxonomy. Psychological Review, 100(4), 674-701. Retrieved from: http://psycnet. apa.org/journals/rev/100/4/674/

Moffitt, T. E. (2003). Life course-persistent and adolescence-limited anti-social behaviour: A 10 year research review and research agenda. In B.B. Lahey, T.E. Moffit, \& A. Caspi (Eds.) Causes of conduct disorder and juvenile delinquency (pp. 49-75). New York: The Guilford Press.

Moffitt, T. E. (2006). A review of research on the taxonomy of life-course persistent versus adolescence-limited antisocial behavior. In F. T. Cullen, J. P. Wright, \& K. R. Blevins, Taking stock: the status of criminological theory. (pp. 277-311). New Brunswick, N.J.: Transaction Publishers.

MoffitT, T. E., \& CAspi, A. (2001). Childhood predictors differentiate life-course persistent and adolescence-limited antisocial pathways among males and females. Development and Psychopathology, 13, 355-375.

Mohr, P., Howells, K., Gerace, A., Day, A., \& Wharton, M. (2007). The role of perspective taking in anger arousal. Personality and Individual Differences, 43, 507-517. doi: 10.1016/j. paid.2006.12.019

Monahan, K. C., Steinberg, L., Cauffman, E., \& Mulvey, E. P. (2009). Trajectories of antissocial behavior and psychosocial maturity from adolescence to young adulthood. Developmental Psychology, 45(6), 1654-1668. doi: 10.1037/a0015862

Mota, C. P., Matos, P. M., \& Lemos, M. S. (2011). Psychometric properties of the social skills questionnaire: Portuguese adaptation of the student form (grades 7 to 12). The Spanish Journal of Psychology, 14(1), 486-499. doi: 10.5209/rev_SJOP.2011.v14.n1.44

Patterson, G. R., \& Yoerger, K. (2002a). A developmental model for early- and late-onset delinquency. In J. B. Reid, G. R. Patterson, \& J. Snyder, Antisocial behavior in children and adolescents: A developmental analysis and model for intervention. (pp.147-172). Washington, DC: American Psychological Association.

Patterson, G. R., \& Yoerger. K. (2002b). Um modelo desenvolvimental da delinquência de início tardio. In A. C. Fonseca (Ed.), Comportamento anti-social e familia: Uma abordagem cientifica (pp. 93-155). Coimbra: Almedina.

Piaget, J. (1965). The moral judgment of the child. Glencoe, Illinois: The Free Press.

Romer, D., Duckworth, A., Sznitman, S., \& Park, S. (2010). Can adolescents learn self-control? Delay of gratification in the development of control over risk taking. Prevention Science, 11, 319330. doi: 10.1007/s11121-010-0171-8

Romer, D., et al. (2009). Executive cognitive functions and impulsivity as correlates of risk taking and problem behavior in preadolescents. Neuropsychologia, 47, 2916-2926. doi: 10.1016/j. neuropsychologia.2009.06.019

Romero, E. Luengo, M. A., \& Sobral, J. (2001). Personality and antisocial behaviour study of temperamental dimensions. Personality and Individual Differences, 31, 329-348. doi: 10.1016/ S0191-8869(00)00139-2

Rutter, M. (2004). Dos indicadores de risco aos mecanismos de causalidade: Análise de alguns percursos cruciais. In A. C. Fonseca (Ed.), Comportamento anti-social e crime: Da infância à idade adulta (pp. 11-38). Coimbra: Almedina. 
Rutter, M., Giller, H., \& Hagell, A. (1998). Antisocial behaviour by young people. Cambridge: Cambridge University Press.

Sampson, R. J., \& Laub, J. H. (2005). A lifecourse view of the development of crime. The ANNALS of the American Academy of Political and Social Science, 602, 12-45. doi: 10.1177/0002716205280075

Schultz, L. H., Barr, D. J., \& Selman, R. L. (2001). The value of a developmental approach to evaluating character development programmes: An outcome study of «Facing history and ourselves». Journal of Moral Education, 30(1), 3-27. doi: 10.1080/0305724012003378

SELMAN, R. L. (1975). Level of social perspective taking and the development of empathy in children: Speculations from a social-cognitive viewpoint. Journal of Moral Education, 5(1), 35-43. doi: $10.1080 / 0305724750050105$

Selman, R. L., \& Adalbjarnardottir, S. (2000). A developmental method to analyze the personal meaning adolescents make of risk and relationship: The case of «drinking». Applied Developmental Science, 4(1), 47-65. doi: 10.1207/S1532480XADS0401_4

STAMs, G. J. et al. (2006). The moral judgement of juvenile delinquents: A metaanalysis. Journal of Abnormal Child Psychology, 34, 697-713. doi: 10.1007/s10802-006-9056-5

Steinberg, L. (2009). Adolescent development and juvenile justice. Annual Review of Clinical Psychology, 5, 459-485. doi: 10.1146/annurev.clinpsy.032408.153603

Steinberg, L. et al. (2009). Age differences in future orientation and delay discounting. Child Development, 80(1), 28-44. doi: 10.1111/j.1467-8624.2008.01244.x

Taborda Simốes, M. C. (2002). Adolescência: Transição, crise ou mudança? Psychologica, 30, 407429.

Thornberry, T. P., \& Krohn, M. D. (2004). O desenvolvimento da delinquência: Uma perspectiva interaccionista. In A. C. Fonseca (Ed.), Comportamento antisocial e crime: Da infancia à idade adulta (pp. 133-160). Coimbra: Almedina.

Tremblay, R. E. (2000). The development of agressive behaviour during childhood: What have we learned in the past century?. International Journal of Behavioral Development, 24(2), 129-141. doi: 10.1080/016502500383232

Tremblay, R. E. (2010). Developmental origins of disruptive behaviour problems: The 'original sin' hypothesis, epigenetics and their consequences for prevention. Journal of Child Psychology and Psychiatry, 51(4), 341-367. doi: 10.1111/j.1469-7610.2010.02211.x

Turiel, E. (2008). The development of morality. In W. Damon, \& R. M. Lerner, Child and adolescent development: An advanced course (pp. 473-514). Hoboken, N.J.: Wiley.

vanlier, P., Vuijk, P., \& Crijnen, A. (2005). Understanding mechanisms of change in the development of antisocial behavior: The impact of a universal intervention. Journal of Abnormal Child Psychology, 33(5), 521-533. doi: 10.1007/s10802-005-6735-7

Zara, G., \& FARrington, D. P. (2010). A longitudinal analysis of early risk factors for adultonset offending: What predicts a delayed criminal career? Criminal Behaviour and Mental Health, 20, 257-273. doi: 10.1002/cbm.763

Zimbardo, P., \& Boyd, J. (2010). The time paradox: Using the new psychology of time to your advantage. London: Rider. 